\title{
Corrigendum: Microenvironment Cell Contribution to Lymphoma Immunity
}

\author{
Deepika Kumar and Mina L. Xu* \\ Departments of Pathology \& Laboratory Medicine, Yale University School of Medicine, New Haven, CT, United States
}

Keywords: lymphoma, microenvironment, T cell subsets, stromal cells, lymphoma exosomes

\section{A Corrigendum on}

Microenvironment Cell Contribution to Lymphoma Immunity

by Kumar, D., and Xu, M. L. (2018). Front. Oncol. 8:288. doi: 10.3389/fonc.2018.00288

In the original article, Boulland et al. (94) and Carbonelle-Puscian et al. (95) were not cited in the article. These references have now been inserted in Mechanisms of Tumor Microenvironment Mediated Immune Evasion and Tumor Progression in NHL, Paragraph Number 2:

Inhibitory enzymes, like indolediamine oxidase (IDO), and phenylalanine oxidase interleukin 4induced gene 1 (IL4I1), secreted by lymphoma associated macrophages and some B-NHL cells also contributes to immune suppression by Treg expansion and inhibition of effector $\mathrm{T}$ cell proliferation and activity $(94,95)$.

The citations for Boulland et al. (94) and Carbonelle-Puscian et al. (95) have also been inserted in the legend for Figure 1:

IDO and IL4I1 are also responsible for recruitment and differentiation of immunosuppressive

Edited and reviewed by: Alexandar Tzankov, Universitätsspital Basel, Switzerland

*Correspondence:

Mina L. Xu Mina.xu@yale.edu

Specialty section:

This article was submitted to Cancer Immunity and Immunotherapy, a section of the journal

Frontiers in Oncology

Received: 05 October 2018

Accepted: 24 October 2018

Published: 08 November 2018

Citation:

Kumar D and XU ML (2018) Corrigendum: Microenvironment Cell Contribution to Lymphoma Immunity. Front. Oncol. 8:522. doi: 10.3389/fonc.2018.00522 Tregs, as well as exhaustion of T-effector cells through CCL22, TGF- $\beta$, and IL-12 secretion. FAS Ligand (FASL) induces apoptosis of CTLs $(94,95)$.

The authors apologize for this error and state that this does not change the scientific conclusions of the article in any way. The original article has been updated.

\section{REFERENCES}

94. Boulland M, Marquet J, Molinier-Frenkel V, Moller P, Guiter C, Lasoudris F, et al. Human IL4I1 is a secreted Lphenylalanine oxidase expressed by mature dendritic cells that inhibits, T-lymphocyte proliferation. Blood (2007). 110:220-7. doi: 10.1182/blood-2006-07-036210

95. Carbonelle-Puscian A, Copie-Bergman C, Martin-Garcia, N, Allory Y, Haioun C, Cremandes, A., et al. The novel immunosuppressive enzyme IL4I1 is expressed by neoplastic cells of several B-cell lymphomas and by tumor-associated macrophages. Leukemia (2009). 23:952-60. doi: 10.1038/leu.2008.380

Conflict of Interest Statement: The authors declare that the research was conducted in the absence of any commercial or financial relationships that could be construed as a potential conflict of interest.

Copyright $\odot 2018$ Kumar and Xu. This is an open-access article distributed under the terms of the Creative Commons Attribution License (CC BY). The use, distribution or reproduction in other forums is permitted, provided the original author(s) and the copyright owner(s) are credited and that the original publication in this journal is cited, in accordance with accepted academic practice. No use, distribution or reproduction is permitted which does not comply with these terms. 